\title{
Dimensi Etis Pelaksanaan Kursus Tes Psikologis (Psikotes)
}

\author{
Adelia Aulia Raganiz ${ }^{1}$, Sumaryati ${ }^{2}$ \\ 1Program Studi Magister Psikologi Profesi, Universitas Ahmad Dahlan, Yogyakarta, Indonesia \\ 2 Prodi Pendidikan Pancasila dan Kewarganegaraan (PPKn), Universitas Ahmad Dahlan, \\ Yogyakarta, Indonesia \\ E-mail: Raganizaul22@gmail.com¹, Sumaryati@ppkn.uad.ac.id ${ }^{2}$
}

\begin{abstract}
Abstrak
Artikel ini membahas tentang dimensi etis pelaksanaan kursus tes psikologi (Psikotes). Tes psikologi ini sering kita temukan pada tahap seleksi di bidang pendidikan atau pekerjaan dengan tujuan untuk menyaring kualitas sumber daya manusia (SDM) yang sesuai dengan kebutuhan. Dengan demikian tes psikologi harus dilakukan dengan baik dan benar. Namun berdasarkan hasil observasi peneliti, masih banyak lembaga yang mengadakan kursus psikotes, agar para peserta dapat lolos pada tahap psikotes ini. Tetapi sebenarnya dalam mengikuti tes psikologi tidak diperlukan persiapan apapun. Kajian ini bertujuan untuk membuktikan implementasi kode etik dalam pelaksanaan kursus psikotes. Jenis penelitian library research. Informasi dikumpulkan dengan melakukan studi pustaka. Simpulan dari penelitian ini ialah masih banyak lembaga yang mengadakan kursus tes psikologi yang di mana hal itu sangat bertentangan dengan hakekat ilmu yang sebagaimana dalam menyampaikan ilmu itu harus bernilai, beretika dan bermoral.
\end{abstract}

Kata Kunci: aksiologi; etis; tes psikologi.

\begin{abstract}
The article examines the ethical issues in administering a psychological assessment course (Psychometric Test). The psychological testing is frequently found at the selection process in the areas of education or work with the aim of filtering out the quality of human resources (HR) according to needs. Thus, psychological testing must be conducted properly and correctly. Based on the results of researchers' observations, there exist dozens of institutions that hold psychological assessment courses, so that participants can pass this psychological testing phase. But actually, taking a psychological test does not require any preparation. This study is intended to demonstrate the implementation of the ethics code in administering the psychological assessment courses. The type of research is library research. The information was collected by conducting literature review. The conclusion of this research is that dozens of institutions conduct psychological assessment courses which are very contrary to the nature of the knowledge as in conveying the knowledge must be valuable, ethical and moral.
\end{abstract}

Keywords: axiology, ethics, psychological test.

\section{Pendahuluan}

Tes psikologi atau yang biasa kita kenal dengan psikotes merupakan alat yang digunakan dalam melakukan penilaian terhadap individu sesuai dengan tujuan dari diberikannya tes tersebut. Tes psikologi bukan merupakan tes karena tidak memiliki arti lulus atau tidak, tetapi tes psikologi ini dapat meramalkan atau mendeteksi individu tersebut sesuai atau tidak menempati suatu posisi berdasarkan hasil dari tes psikologi. Adapun pengertian tes psikologi menurut Anastasi (1990) bahwa tes psikologi pada dasarnya merupakan ukuran objektif dan standar dari sampel perilaku. Pada dasarnya tes psikologi itu kumpulan pertanyaan-pertanyaan yang harus dijawab atau tugas-tugas yang harus dikerjakan dan akan memberikan informasi mengenai aspek psikologis tertentu berdasarkan dari jawaban individu terhadap pertanyaan-pertanyaan atau cara individu melakukan tugas-tugas tersebut (Irfan dkk., 2010).

Tes psikologi menurut Irfan dkk (2010) dari segi penggunaannya sangat bermacam-macam, kita bisa membedakan berdasarkan usia, bidang pekerjaan, bentuk bahan (alat) dan jenisnya dan aspek yang hendak diukur. Berdasarkan tingkat usia dibedakan: untuk anak-anak dan dewasa, berdasarkan bidang tugas (pekerjaan)Ak: untuk bidang pendidikan, perusahaan, dan militer, berdasarkan bentuk alat: untuk bahan cetakan, tulis menulis, alat mainan, peralatan yang lebih komplek dan lain-lain, berdasarkan aspek yang diukur: untuk tes kecerdasan, tes bakat, tes kepribadian, dan 
tes minat. Tes psikologi dapat dibedakan dari bentuknya yaitu tes proyeksi dan tes non-proyeksi. Tes proyeksi adalah tes yang disusun atas dasar penggunaan mekanisme proyeksi. Tes non-proyeksi adalah tes kepribadian yang disusun dengan tidak mempertimbangkan adanya proyeksi.

Dalam pemeriksaan psikologi individu tidak semua alat tes psikologi dipakai, pemakaian alat tes psikologi harus sesuai dengan keperluan dan tujuan dari pemeriksaan. Data-data yang diperoleh dari hasil tes psikologi dapat dipakai sebagai bahan pertimbangan untuk mengambil keputusan, membuat perencanaan dan penanganan kasus tertentu (Irfan dkk., 2010). Menurut Irfan (2010) tes psikologi dapat bermanfaat untuk keperluan dalam berbagai bidang : bidang pendidikan dapat bermanfaat untuk seleksi calon didik, penjurusan atau pemilihan program studi, perencanaan studi anak didik, program bimbingan karir dan penanganan kasus tertentu, bidang pekerjaan, industry dan organisasi dapat bermanfaat untuk seleksi dan penempatan karyawan, mutase dan promosi, perencanaan dan pelaksanaan program pelatihan bagi karyawan dll, bidan militer dapat bermanfaat untuk seleksi penempatan anggota militer, mutase promosi jabatan dan perencanaan karir, penanganan kasus tertent, dan pada bidang klinis bermanfaat untuk diagnosis, prognosis, treatment, deteksi perkembangan penyembuhan.

Pada beberapa alat tes psikologi memang sangat dijaga mengenai kerahasiaannya terutama alat tes yang menggali tentang kepribadian dan kecerdasan individu. Ada beberapa alat tes psikologi yang boleh diberikan kepada mahasiswa atau sarjana psikologi, itu juga hanya mengajarkan bagaimana cara mengadministrasikannya tanpa mengajarkan secara mendalam mengenai cara menginterpretasikannya. Penelitian yang dilakukan oleh Ready dan Veague (2014) mengenai pelatihan asesmen psikologi yang dimana pada penelitian tersebut subjeknya ialah individu-individu yang mendalami ilmu psikologi khususnya psikologi klinis. Hal ini memperjelas bahwa alat tes psikologi ini sangat dijaga kerahasiaannya tidak diajarkan ke orang lain yang tidak mendalami bidang psikologi dan tidak diperbolehkan untuk menyebar luaskan alat tes psikologi.

Tes psikologi memiliki banyak manfaat khususnya dalam seleksi baik dibidang pendidikan, pekerjaan maupun militer. Tidak jarang para peserta didik, calon pegawai, pegawai yang ingin dipromosikan, calon anggota militer atau kepolisian dan lain-lain gagal diterima pada suatu instansi karena gagal pada tahap tes psikologi. Hal tersebut terkadang membuat para peserta yang pernah gagal di tes psikologi atau yang ingin mengikuti tes psikologi, jadi mengikuti kursus tes psikologi atau belajar tes-tes psikologi dari buku dengan harapan akan berhasil mengerjakan soal-soal tes psikologi. Sepertinya hal seperti itu tidak diperlukan karena dalam menghadapi tes psikologi tidak diperlukan persiapan apapun. Kursus tes psikologi ini sangat bertentangan sekali dengan ilmu sebagaimana mestinya. Di dalam kajian aksiologi ilmu yang dimana aksiologi ilmu ini membahas tentang nilai, norma dan etika. Aksiologi diartikan sebagai teori nilai yang berkaitan dengan kegunaan dari pengetahuan yang diperoleh (Suriasmantri, 2010).

Kursus tes psikologi ini sering kita jumpai di internet. Pelatihan bimbingan tes psikologi untuk khalayak umum merupakan bentuk pelanggaran yang tidak etis dalam menyampaikan ilmu. Di dalam kursus tes psikologi ini biasanya para peserta diberikan latihan soal yaitu berupa tes psikologi dan para peserta diajarkan cara mengerjakan dan memilih pilihan jawaban agar sesuai dengan kriteria yang dibutuhkan oleh instansi atau universitas. Latihan soal yang diberikan itu biasanya adalah soal-soal asli dari alat tes psikologi yang bersifat rahasia. Kursus tes psikologi ini biasanya dipimpin atau diajarkan oleh tutor dan tutornya itu dari kalangan yang berpengalaman dalam pengetesan psikote atau sarjana psikologi yang seharusnya tidak menyebarluaskan alat tes psikologi. Alat tes psikologi ini bersifat rahasia. Kebocoran alat tes psikologi ini sangatlah meresahkan karena tidak ada pihak-pihak yang dapat mempertanggung jawabkannya.

Di dalam kursus tes psikologis ini biasanya membahas tentang tips and trick mengerjakan soalsoal tes psikologis. Ada prinsip etika dalam penggunaan tes psikologis yang di atur dalam American Psychological Association (APA) "Ethical Standards of Psychologist" (1968),terdapat Sembilan belas etika prinsip tetapi hanya ada dua yang relevan dengan fenomena ini. (1) Prinsip Keamanan tes (Test Security) tes psikologis harus dijaga keamanannya yang dimana tes psikologis ini adalah alat yang professional yang melakukannya juga oleh orang yang professional yaitu orang-orang yang belajar dalam bidang psikologi (minimal sarjana S1 psikologi). Dalam pembuatan tes psikologi juga dijaga keamanannya dengan menggunakan kompetensi teknis yang tepat dan harus sudah dibakukan. Maka sangatlah penting dalam menjaga keamanan tes psikologis agar hasilnya juga valid. (2) Prinsip interpretasi tes (test interpretation) dalam menginterpretasikan tes psikologis ini seperti material dan penskoran tes psikologis semestinya diberikan ke individu-individu yang berwenang menggunakannya, karena dalam kursus tes psikologis ini biasanya para pesertanya diajarkan cara menginterpretasikannya seperti tes psikologi ini untuk mengukur apa dan cara pengerjaannya agar bisa sesuai dengan kebutuhan. 
Kursus tes psikologis ini selain bertentangan dengan etika dengan APA juga sangat bertentangan dengan kode etik psikologi yang disusun oleh Himpunan Psikologi Indonesia (HIMPSI). Kode etik itu disusun bukan hanya sekedar bacaan atau pajangan saja, namun harus diimplementasikan dalam melakukan pekerjaan, dinilai tingkat implementasinya melalui mekanisme monitoring, kemudian dievaluasi dan diupayakan perbaikan melalu konsesus (Maani, 2010). Dimensi etis pelaksanaan kursus tes psikologis ini yang di kaji dengan pendekatan aksiologi. Di dalam kajian aksiologi ini akan membahas antara etika, nilai dan norma. Pengadaan kursus tes psikologi ini apakah sesuai dengan etika dalam menyampaikan ilmu. Hal ini sangat menarik untuk diteliti, sehingga peneliti ingin membahas lebih lanjut mengenai "Dimensi Etis Pelaksanaan Kursus Tes Psikologi (Psikotes): Kajian Aksiologi"

\section{Metode}

Artikel ini ditulis dengan menggunakan metode penelitian library research. Adapun metode penelitian library research ini dengan cara studi pustaka dan journal review. Adapun teknik analysis data dengan objek penelitian, telaah isi buku, artikel, dilanjutkan kategorisasi hasil telaah berdasarkan tujuan kajian, diakhiri dengan penyimpulan

Artikel ini juga ditulis berdasarkan kajian literatur filsafat. Kajian filsafat yang diperdalam dalam penelitian ini adalah aksiologi. Aksiologi ialah teori tentang nilai-nilai. Nilai adalah suatu kualitas abstrak yang membuat sesuatu hal itu menjadi bermakna, berbobot, sehingga yang memilikinya merasa puas batinnya. Jadi, jelas dalam artikel ini akan membahas mengenai nilai-nilai dalam rangka penerapan suatu disiplin ilmu yang dikaji secara ilmiah. Dalam artikel ini juga akan fokus membahas mengenai etika pelaksanaan kursus psikologi yang menyimpang dari nilai-nilai yang berlaku dalam kode etik psikologi Indonesia.

\section{Hasil Dan Pembahasan}

\section{a. Tes Psikologis dan Kursus Tes Psikologis}

Tes dalam bahasa inggris biasa kita kenal dengan test, dalam bahasa latin biasa dikenal degan testum yang artinya adalah wadah atau mangkok untuk memeriksa logam atau alat untuk menentukan mutu (Irfan dkk., 2010). Tes juga memiliki arti sebagai ujian yang mengukur atau menilai hasil kerja (performance), kapabilitas, dan sifat seseorang. Kemudian kata psikologi berasal dari bahasa Yunani yaitu psyche (jiwa) dan logos (ilmu). Jadi psikologi secara bahasa diartikan sebagai ilmu tentang jiwa atau ilmu yang mempelajari jiwa. Adapun pengertian psikologi menurut Glassman dan Hadad (2009) perilaku overt dan pengalaman sadar yang antara lain terdiri dari pikiran dan perasaan. Pengertian tes psikologi menurut Anastasi (1990) tes psikologi pada dasarnya merupakan ukuran objektif dan standar dari sampel perilaku.

Tes psikologi ini memiliki macam-macam prosedur dan alat dalam pemeriksaan psikologi tergantung pada segi-segi kehidupan kejiwaan atau aspek-aspek kejiwaan dan perilaku yang hendak diperiksa. Macam-macam prosedur dan alat dalam pemeriksaan psikologi menurut Irfan (2010) dapat dibedakan berdasarkan tingkat usia : tes untuk anak-anak dan dewasa, berdasarkan bidang tugas : tes untuk bidang pendidikan, perusahaan, dan militer, berdasarkan bentuk tes : bahan cetakan, tulis menulis, alat mainan, peralatan-peralatan yang lebih komplek (rumit) dan sebagainya, berdasarkan aspek yang diukur : tes kecerdasan, tes bakat, tes kepribadian, dan tes minat.

Alat tes psikologi memiliki 2 bentuk, alat tes proyektif dan non-proyektif. Alat tes proyektif ialah alat tes yang proyeksi cenderung menghasilkan cerita atau cerminan dari dalam diri individu yang sedang dialaminya, contoh alat tes proyektif ialah tes-t

es grafis, TAT, Rorschach dan lain-lain. Alat tes non-proyektif lebih cenderung tes-tes yang bersifat untuk mengetahui intelegensi seseorang dan sudah memiliki norma atau terstandarisasi, contoh alat tes non-proyektif ialah tes IQ, tes IST, tes Binet dan lain-lain.

Alat tes psikologi merupakan salah satu alat yang digunakan untuk melakukan pemeriksaan psikologi terhadap individu. Proses pemeriksaan psikologi ini lebih dikenal dengan sebutan asesmen psikologi. Asesmen psikologi ini sangat diperlukan dalam berbagai bidang seperti dalam bidang pendidikan dapat diperlukan untuk seleksi calon anak didik, penjurusan atau pemilihan program studi, perencanaan studi anak didik pada tingkat yang lebih tinggi, program bimbingan karir dan lain-lain, bidang pekerjaan, industri dan organisasi sangat diperlukan untuk seleksi dan penempatan karyawan, mutase dan promosi karyawan, perencanaan dan pelaksanaan program pelatihan bagi karyawan dan lain-lain, dalam bidang militer diperlukan untuk seleksi dan penempatan anggota militer, mutas, promosi 
jawaban dan perencanaan kariri, dan dalam bidang klinis diperlukan untuk diagnosis, prognosis, treatment dan deteksi perkembangan atau kemajuan proses penyembuhan (Irfan dkk., 2010).

Alat tes psikologi ini salah satu alat yang sangat diperlukan ketika melakukan pemeriksaan psikologi selain wawancara dan observasi. Namun sangat disayangkan beberapa alat tes psikologi sudah tidak rahasia lagi karena banyak oknum yang tidak bertanggung jawab membocorkan soal-soal tes psikologi yang berlaku. Menyebar luasnya alat tes psikologi ini disebebkan oleh beberapa faktor ada yang karena beredarnya soal-soal tes psikologi di toko buku atau internet, kemudian adanya oknum yang tidak bertanggung jawab melakukan kursus tes psikologi. Sebenarnya dalam mengerjakan soal dalam tes psikologi tidak diperlukan persiapan apapun, karena tes psikologi itu ingin mengukur keadaan sebenarnya dalam diri individu tanpa adanya proses latihan seperti mengerjakan soal dan sebagainya. Kursus tes psikologi ini sudah sangat meresahkan, selain tersebarluasnya alat tes psikologi juga di dalam kursus tersebut para peserta diajarkan cara mengerjakan tes psikologi agar hasil interpretasinya baik dan mereka mengajarkan hasil interpretasi kepada individu yang tidak memiliki latar belakang pendidikan psikologi. Kemudian kursus psikologi ini juga terkadang mengiming-imingi para peserta dengan jaminan lulus tes psikologi. Di dalam kursus tes psikologi ini biasanya ada yang mengajarkan dan yang mengajarkannya itu ialah sarjana psikologi yang sebenarnya tidak memiliki kompetensi untuk melakukan interpretasi dan lain-lain. Para peserta yang mengikuti kursus tes psikologi ini biasanya diakhir kursus mendapatkan sertifikat sebagai bukti pernah mengikuti kursus tes psikologi. Kursus tes psikologi ini dapat dilakukan secara online maupun offline.

\section{b. Dimensi Etis Sebagai Bagian Aksiologi}

Aksiologi berasal dari bahasa Yunani yang terdiri dari kata axios yang berarti nilai dan logos yang artinya teori. Jadi Aksiologi adalah teori tentang nilai-nilai. Nilai adalah suatu kualitas abstrak yang membuat sesuatu hal itu menjadi bermakna, berbobot, sehingga yang memilikinya merasa puas batinnya. Landasan aksiologis pengembangan ilmu merupakan sikap etis yang harus dikembangkan oleh seorang ilmuwan, terutama dalam kaitannya dengan nilai-nilai yang diyakini kebenarannya, sehingga suatu aktivitas ilmiah senantiasa dikaitkan dengan kepercayaan, ideologi yang dianut oleh masyarakat atau bangsa, dan tempat ilmu itu dikembangkan (Anas \& Nukman, 2018).

Di dalam kajian aksiologi ini membahas tentang nilai, norma, etika dalam ilmu atau dalam menyampaikan sebuah ilmu. Konsep ilmiah itu bersifat abstrak yang menjelma dalam bentuk konkret yang berupa teknologi. Teknologi ini diartikan sebagai penerapan konsep ilmiah dalam memecahkan masalah-masalah praktis baik yang berupa perangkat keras (hardware) maupun perangkat lunak (software) (Suriasmantri, 2010). Di dalam kajian aksiologi ini ada yang dikenal dengan "kontemplasi ke manipulasi" dalam tahap manipulasi inilah masalah moral muncul kembali namun dalam kaitan dengan faktor-lain. Pada tahap konteplasi ini masalah moral berkaitan dengan metafisik keilmuan, sedangkan dalam tahap manipulasi ini masalah moral berkaitan dengan cara penggunaan pengetahuan ilmiah. Dalam tahap penerapan konsep terdapat masalah moral maka ditinjau dari segi aksiologi keilmuan. Aksiologi diartikan sebagai teori nilai yang berkaitan dengan kegunaan dari pengetahuan yang diperoleh (Suriasmantri, 2010).

Etika merupakan salah satu cabang aksiologi ilmu yang banyak membahas menganai masalah nilai-baik atau buruk. Etika memiliki 3 pengertian : Pertama, etika bisa dipakai dalam arti nilai-nilai atau norma-norma moral yang menjadi pegangan seseorang atau suatu kelompok dalam mengatur tingkah lakunya (Rizal \& Munir, 2001). Kedua, etika sebagai ilmu yang menyelidiki tentang tingkah laku moral dapat dihampiri berdasarkan 3 macam pendekatan yaitu etika desriptif, etika normative dan etika metaetika. Ketiga, etika tidak hanya berkutat pada hal-hal teoritis, namun juga terkait erat dengan kehidupan konkret, sehingga etika sangat bermanfaat (Bertens, 1993).

Dalam menyampaikan ilmu diperlu dilakukan secara etis, pengertian etis menurut Kamus Besar Bahasa Indonesia (2016) ialah berhubungan atau sesuai dengan etika, sesuai dengan asas perilaku yang disepakati secara umum. Jadi etis ialah apabila individu berperilaku sesuai dengan etika yang ada. Adapun etika dalam aksiologi ilmu menurut jurnal yang ditulis Sya'roni (2014) yang pertama, nilai logika: benar-salah nilai mengenai benar atau salahnya Tindakan/kejadian. Dalam hal ini nilai logika berkaitan dengan tindakan/ kejadian yang dilakukan seseorang. Kedua, nilai etika : nilai tentang baik buruk nilai tentang baik-buruk yang berkaitan dengan perilaku manusia. Jadi bagaimana kita menilai perilaku individu tanpa mengkaitkan dengan yang lain. Ketiga, nilai estetika : nilai tentang indahjelek nilai yang berkaitan dengan keindahan penampilan fisik, bukan nilai etik. Jadi yang dinilai ialah tampilannya bukan perilakunya.

Etis dalam berperilaku yang sesuai dengan etika yang berlaku disuatu organisasi atau kelompok biasanya telah dibuat oleh suatu organisasi atau kelompok tertentu. Pada kasus ini etis berperilaku seorang ilmuan psikologi harus harus sesuai dengan nilai-nilai atau norma yang tertulis 
dalam Kode Etik Psikologi yang telah disusun oleh Himpunan Psikologi Indonesia (HIMPSI). Apabila perilaku ilmuan psikologi dan psikolog tidak sesuai dengan kode etik psikologi maka akan ada sanksi yang harus diterimanya. Dimensi etis seorang ilmuan psikologi dan psikolog telah diatur di kode etik psikologi, perilaku apa saja yang boleh dan tidak boleh dilakukan.

\section{c. Dimensi Etis Pelaksanaan Kursus Tes Psikologis (Psikotes)}

Etis ialah apabila individu berperilaku sesuai dengan etika. Kemudian pengertian etika menurut Rizal dan Munir (2001) etika bisa dipakai dalam arti nilai-nilai atau norma-norma moral yang menjadi pegangan seseorang atau suatu kelompok dalam mengatur tingkah lakunya. Etika juga berarti kumpulan asas-asas atau nilai moral seperti misalnya etika dalam menyampaikan ilmu psikologi harus sesuai dengan kode etik psikologi yang telah disusun oleh HIMPSI.

Kursus Tes Psikologi ialah suatu lembaga yang mengajarkan berbagai macam tes psikologi beserta tips and trik cara pengerjaannya. Didalam kursus tes psikologi ini biasanya para peserta diminat untuk mengerjakan soal psikotes, soal psikotes ini biasanya merupakan alat tes psikologi yang biasa digunakan seperti IST, Tes Grafis dan lain-lain dan pada kursus ini dipimpin oleh seorang tutor yang akan mengajarkan bagaimana cara memilih jawaban yang paling tepat agar sesuai dengan kriteria yang dibutuhkan oleh perusahaan ataupun universitas.

Di dalam kursus tes psikologi, para peserta mendapatkan 1 orang tutor yang akan mengajarkan kepada para peserta bagaimana cara memilih jawaban yang paling tepat agar sesuai dengan kriteria yang dibutuhkan oleh perusahaan ataupun universitas. Tutor pengajar itu biasanya adalah ilmuwan psikologi dari strata 1 (Sarjana psikologi). Hal ini tidak sesuai dengan pengertian ilmuwah psikologi yang tertulis di kode etik psikologi (2010, hal. 12) pasal (1) ayat (4), yang berbunyi :

"Ilmuwan psikologi adalah ahli dalam bidang ilmu psikologi dengan latar belakang pendidikan strata 1 dan/atau strata 2 dan/atau strata 3 dalam bidang psikologi. Ilmuwan psikologi memiliki kewenangan untuk memberikan layanan psikologi yang meliputi bidang-bidang penelitian, pengajaran, supervisi dalam pelatihan, layanan masyarakat, pengembangan kebijakan, intervensi sosial, pengembangan instrument asesmen psikologi, pengadministrasian asesmen, konseling sederhana, konsultasi organisasi; perancangan dan evaluasi program. Ilmuwan psikologi dibedakan dalam kelompok ilmu murni (sains) dan terapa"

Seperti yang telah disebutkan dalam kode etik psikologi bahwa seorang ilmuwan psikologi hanya memiliki kewenangan untuk memberikan layanan psikologi yang meliputi bidang penelitian, pengajaran, supervisi dalam pelatihan dan lain-lain. Seorang ilmuwan psikologi tidak berhak untuk melakukan sebuah kursus atau bimbingan dalam mengerjakan tes psikolog, apalagi sampai memberitahukan bagaimana cara memilih jawaban agar sesuai dengan kriteria yang diharapkan oleh sebuah instansi atau universitas.

Dalam kursus tes psikologi, para peserta diberikan latihan soal yang berupa alat tes psikologi yang seharusnya bersifat rahasia. Hal ini sangat bertentangan dengan kode etik psikologi (2010, hal. 113) pasal (6) ayat (1) yang berbunyi:

"Psikolog dan/atau ilmuwan psikologi wajib menjaga kelengkapan dan keamanan instrument/alat tes psikologi, data asesmen psikologi dan hasil asesmen psikologi sesuai dengan kewenangan dan sistem pendidikan yang berlaku, aturan hukum dan kewajiban yang telah tertuang dalam kode etik"

Seharusnya para ilmuwan psikologi/psikolog harus mampu menjaga kelengkapan dan keamanan alat tes. Jangan sampai alat tes yang bersifat rahasia itu sampai tersebar kepada orang dari luar kalangan psikologi atau bahkan orang dari luar kalangan psikologi itu mengetahui kunci jawaban dan cara menginterpretasikan alat tes psikologi, karena alat tes psikologi adalah senjata kita yang membedakan kita sebagai ilmuwan psikologi/psikolog dengan ilmuwan yang lain.

Dari penjelasan di atas dapat peneliti simpulkan bahwa dalam kursus tes psikologi ini sangat bertentangan sekali dengan ilmu sebagaimana harusnya, menurut kajian aksiologi, aksiologi diartikan sebagai teori nilai yang berkaitan dengan kegunaan dari pengetahuan yang diperoleh (Suriasmantri, 2010). Ilmu psikologi itu sangat berguna tetapi para individu yang tidak bertanggung jawab melaksanakan kursus tes psikologi. Masalah moral berkaitan dengan cara penggunaan pengetahuan ilmiah. Dalam tahap penerapan konsep terdapat masalah moral maka ditinjau dari segi aksiologi keilmuan. 
Adanya kursus tes psikologi ini sangat bertentangan dengan etika yang tertulis di dalam buku kode etik psikologi yang ditulis oleh HIMPSI. Kode etik psikologi ini adalah etika yang berlaku disuatu organisasi atau kelompok yang pada kasus ini adalah kelompok HIMPSI. Perilaku yang melanggar kode etik psikologi ini berarti sangat tidak etis.

Kursus tes psikologi ini sangat bertentangan dengan nilai dan norma yang tertulis di dalam kode etik psikologi. Jadi sebaiknya memang kursus tes psikologi ini diberhentikan saja, karena kursus tes psikologi ini tidak sesuai dengan apa yang sudah di atur dalam buku kode etik psikologi tentang pengertian layanan psikologi yang tertulis dalam Pasal (1) ayat (5) kode etik psikologi (2010, hal. 13) ialah:

"Layanan Psikologi adalah segala aktifitas pemberian jasa dan praktik psikologi dalam rangka menolong individu dan/atau kelompok yang dimaksudkan untuk pencegahan, pengebangan dan penyelesaian masalah-masalah psikologis. Layanan psikologi dapat berupa praktik konseling dan psikoterapi; penelitian; pengajaran; supervise dalam pelatihan; layanan masyarakat; penegmbangan kebijakan; intervensi sosial dan klinis; pengembangan instrument asesmen psikologi; penyelenggaraan asesmen; konseling karir dan pendidikan; konsultasi organisasi; aktifitas-aktifitas dalam bidang forensic; perancangan dan evaluasi program dan administrasi"

Jadi apa yang ada di kursus tes psikologi ini bertentangan dengan kode etik psikologi. Jadi baiknya di dalam kursus tes psikologi itu tidak perlu memberi latihan soal kepada pesertanya dengan menggunakan alat tes psikologi yang asli tetapi bisa dengan melakukan wawancara dengan peserta dengan membicarakan orientasi masa depan dan kemudian para tutor mengarahkan bagaimana baiknya. Bisa juga dengan mengadakan pelatihan kepada peserta seperti pelatihan motivasi, kemudian pelatihan mengambil keputusan atau melatih kepercayaan diri para peserta, sehingga nantinya para peserta dapat lebih percaya diri lagi dengan pilihannya. Jadi sebaiknya kursus tes psikologi ini di berhentikan dan diubah dengan memberikan wawancara dan pelatihan.

\section{Simpulan dan Saran}

Tes psikologi atau psikotes ini sangat bermanfaat untuk beberapa bidang, seperti bidang pendidikan, bidang pekerjaan dan organisasi, bidang militer, bidang klinis dan lain-lain. Tes psikologi ini biasa digunakan untuk seleksi baik di instansi atau universitas. Psikotes ini sering menjadi tahap dalam seleksi yang paling ditakuti karena banyak orang yang gagal dalam tahap psikotes ini. Banyak individu yang berpikir bahwa dalam mengikuti tes psikologi ini diperlukan latihan, padahal dalam mengikuti tes psikologi tidak diperlukan persiapan apapun yang penting melaksanakan petunjuk atau perintah yang diberikan.

Kursus tes psikologi, banyak individu yang mengikuti kursus tes psikologi dengan harapan dapat lulus seleksi instansi atau universitas. Di dalam mengikuti kursus tes psikologi ini para peserta diajarkan untuk menjawab dan memilih jawaban agar sesuai dengan kriteria yang diharapkan oleh instansi atau universitas. Di dalam kursus tes psikologi ini juga peserta diberikan soal latihan tes psikologi yang berupa alat tes psikologi yang asli yang bersifat rahasia. Hal ini sangat bertentangan dengan hakekat ilmu yang sebagaimana dalam menyampaikan ilmu itu harus bernilai, beretika dan bermoral. Mengajarkan atau memberitahu cara pengerjaan tes psikologi dan menyebarluaskan alat tes psikologi itu adalah salah satu bentuk pelanggaran kode etik psikologi.

Saran untuk penelitian selanjutnya semoga bisa membuat penelitian pelanggaran kode etik ini menjadi data empiris dan saran untuk lembaga yang menaungi psikologi Indonesia semoga bisa bertindak tegas pada oknum-oknum tidak bertanggungjawab.

\section{Daftar Pustaka}

Anas, M., \& Nukman, I. (2018). Filsafat IImu: Orientasi Ontologis, Epistemologis, dan Aksiologis Keilmuan (E. Kuswandi (Ed.)). PT. Remaja Rosdakarya.

Anastasi, A. (1990). Psychological Testing (6th ed). Company.

APA. (1968). Ethical standards of psychologists. The American psychologist, 23(5), 357-361. https://doi.org/10.1037/h0037782

Bertens, K. (1993). Etika. PT. Gramedia Pustaka Utama.

Glassman, W. ., \& Hadad, M. (2009). Approaches to Psychology. (5th Editio). Berkshire: Open University Press.

Himpunan Psikologi Indonesia, H. (2010). Kode Etik Psikologi Indonesia.

Irfan, S., Rustam, A., Wirawan, Y. G., Wulan, R., Wimbarti, S., Harjito, P., Azwar, S., \& Kumara, A. 
(2010). Bunga Rampai Psikologi Pendidikan.pdf. Pustaka Pelajar.

KBBI. (2016). Kamus Besar Bahasa Indonesia.

Maani, D. K. (2010). Etika Pelayanan Publik. Jurnal Demokrasi, 9 No.1(1), 61-70. http://ejournal.unp.ac.id/index.php/jd/article/view/1415

Ready, R. E., \& Veague, H. B. (2014). Training in psychological assessment: Current practices of clinical psychology programs. Professional Psychology: Research and Practice, 45(4), 278-282. https://doi.org/10.1037/a0037439

Rizal, M., \& Munir, M. (2001). Filsafat Ilmu. Pustaka Pelajar.

Suriasmantri, J. S. (2010). Filsafat Ilmu : Sebuah Pengantar Populer. Pustaka Sinar Harapan.

Sya'roni, M. (2014). Etika keilmuan : Sebuah Kajian Filsafat IImu. Teologia, 25(Januari-Juni 2014), 245270. http://journal.walisongo.ac.id/index.php/teologia/article/download/346/315

Anas, M., \& Nukman, I. (2018). Filsafat IImu: Orientasi Ontologis, Epistemologis, dan Aksiologis Keilmuan (E. Kuswandi (Ed.)). PT. Remaja Rosdakarya.

Anastasi, A. (1990). Psychological Testing (6th ed). Company.

APA. (1968). Ethical standards of psychologists. The American psychologist, 23(5), 357-361. https://doi.org/10.1037/h0037782

Bertens, K. (1993). Etika. PT. Gramedia Pustaka Utama.

Glassman, W. ., \& Hadad, M. (2009). Approaches to Psychology. (5th Editio). Berkshire: Open University Press.

Himpunan Psikologi Indonesia, H. (2010). Kode Etik Psikologi Indonesia.

Irfan, S., Rustam, A., Wirawan, Y. G., Wulan, R., Wimbarti, S., Harjito, P., Azwar, S., \& Kumara, A. (2010). Bunga Rampai Psikologi Pendidikan.pdf. Pustaka Pelajar.

KBBI. (2016). Kamus Besar Bahasa Indonesia.

Maani, D. K. (2010). Etika Pelayanan Publik. Jurnal Demokrasi, 9 No.1(1), 61-70. http://ejournal.unp.ac.id/index.php/jd/article/view/1415

Ready, R. E., \& Veague, H. B. (2014). Training in psychological assessment: Current practices of clinical psychology programs. Professional Psychology: Research and Practice, 45(4), 278-282. https://doi.org/10.1037/a0037439

Rizal, M., \& Munir, M. (2001). Filsafat Ilmu. Pustaka Pelajar.

Suriasmantri, J. S. (2010). Filsafat IImu : Sebuah Pengantar Populer. Pustaka Sinar Harapan.

Sya'roni, M. (2014). Etika keilmuan : Sebuah Kajian Filsafat IImu. Teologia, 25(Januari-Juni 2014), 245270. http://journal.walisongo.ac.id/index.php/teologia/article/download/346/315. 